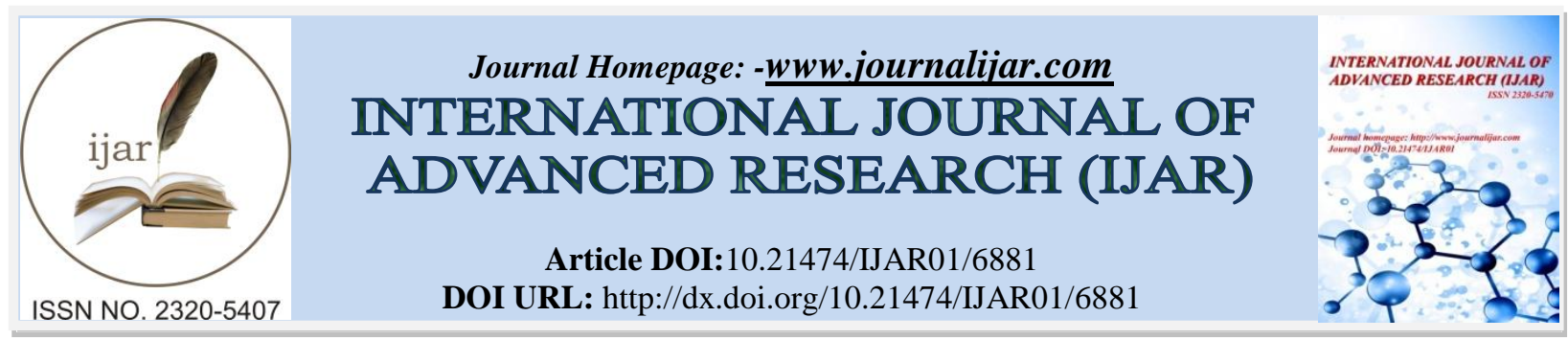

RESEARCH ARTICLE

\title{
MANAGEMENT BY WALKING AROUND: A CRITERIA FOR EVIDENCE BASED MANAGEMENT.
}

Okeke Raymond Njelita and Chukwuladi Eke.

1. Department of Business Administration and Management Imo State Polytechnic Umuagwo.

2. Department of Social Science Education Imo State University, Owerri.

\section{Manuscript Info}

(...........................

Manuscript History

Received: 08 February 2018

Final Accepted: 10 March 2018

Published: April 2018

Keywords:-

Management, walking around, evidence, organization, performance.

\begin{abstract}
This work is on understanding management by working around and its effect on organizational performance. The success of an organization is mostly dependent on the quality and quantity of information at the disposal of its management. This avails mangers the opportunity of obtaining first hand information and saves them managing out of ignorance or relying sole on information that come through lines of authority which in most cases have been adulterate in favor of the source. The objectives of the study were, to identify managerial skills that aid management by walking around; to ascertain conditions for successful management by walking around and to determine effects of management by walking around on organizational performance. The work concluded that, human resources skill is essential ingredient of management by working around; communication skill is a means by which managers send and receive messages; managers align management by walking around with organization objectives; respect for unity of command is necessary; management by walking around cannot be done by proxy; it strengthens relationship; it also provide first hand information and management by walking around is a source of motivation. Therefore the work recommended that managers should have technical competence, vision and listening ability. The process of management, walking around should be continuous; manager should ask questions; they should be fair and just; they should be honest in their judgment, and they should make sure that it contributes to realization of objectives.
\end{abstract}

Copy Right, IJAR, 2018,. All rights reserved.

\section{Introduction:-}

Every business organization needs information to take decisions. The need for accurate, pertinent and timely information at various stages of organization's decision process is vital to managers. Because it creates the awareness and exposes challenges facing organization in which it is to find solutions. For example vital information to modify products or services to suite customers comes from the interaction with organizational members, internal functions, external suppliers, distributors and consumers. This is important in order to ensure that managers do not manage out of ignorance or relying solely on information that comes through lines of authority which in most cases had been adulterated in favor of the source. This misleads managers to waste organizations time, money and materials. And often leads organizations to move in the wrong direction. (Iyer, 2009:85). 
Relying on managing behind the desk results to managers isolated from realities in the organization. Nothing is more befitting than knowing what actually is happening within and learn from it. It requires personal involvement, good listening abilities, recognizing that most people in organizations want to contribute. This can be harnessed if managers display sincerity and civility in their dealings with other organization members. It is only in the light of that the organizational members perceive management by walking around as part of broader understanding the feelings and problems. Managers not only take interest in contributions to objectives of individual workers, but also explore into their personal and family lives in order to strengthen bond of friendship and trust within organizations.

This is with the intention of appealing to the minds of organizational members that management by walking around is not for victimization, intimidation, criticism etc. But catching people, infusing fears, conveying a sense of we are with you for improving organizational performance. It proves that managers have confidence in the abilities of staff. This allows for easy communication and feedback and encourages participation of all towards the growth of organizations. Thereby improve management, subordinate relationship (Imaga and Ewurum, 1998:199).

\section{Origin Of Management By Walking Around:-}

There have been several stories built up around the origin of Management by Walking Around, but the most popular one was the one associated with Hewlett-Packard (HP). Hewlett and Packard were the founders of HP Company and were using the concept as a technique for running their organization. They believed in walking around within their organization which enabled them to interact with their staff; saw things for themselves and offer correction if the need be. This management concept relates to Japanese Gemba Walk. 'GenchiGenbutsu' means go and see for yourself. The place one goes to, is the 'Gemba', the place where something is happening in this case is organizations (McConmack, 2009:16).

Management by Walking Around was first mentioned by Hewlett and Packard in response to an enquiry by group of management scholars who sought to find out the secret of the success of HP Company. In response to the questions of secrets for their company's success, they replied that they were using no known management principles or theories. They stated emphatically that they were using Management by Walking Around. This concept came as a surprise to management scholars and commentators.

Although this statement was made with intention to slight management philosophers, it gained acceptance in management practice (Stones, 1978:520). And the concept was popularized in 1982, by Tom Peter and Robert Waterman in their book "Search for Excellence: Lessons from American Best Run Companies". The book describes Management by Walking Around as getting management off the office. At HP, where the approach has been practiced from 1973, managers were encouraged to know their staff, understand their work and make themselves accessible.

\section{Objectives of the Study:-}

1. To identify managerial skills that aid Management by Walking Around.

2. To ascertain conditions for successful Management by Walking Around.

3. To determine effects of Management by Walking Around on organizational performance.

\section{Concept Of Management By Walking Around:-}

According to Peter and Waterman (1982:360), Management by Walking Around is getting managers out of office. This permits managers to step back from day to day activities and get a fresh perspectives on the current and future direction their organization and its industry. Hewlett and Packard (HP) describe the concept as a technique marked by personal involvement, good listening skills and the recognition that everybody in organizations do good job. It calls on managers to be alive and alert to their responsibilities. And suggests that managers at all levels must not depend solely on information which comes through line of authority which in most cases been adulterated in favor of the source.

The term Management by Walking Around is a management concept which involves managers wandering around in an unstructured manner throughout the organization at random to check employees or equipment, the status of an ongoing work (Wikipedia, 2000:6). Managers are mired in the complexity of their tasks. They believe that every employee understands the basic building blocks of how their organizations are working. Few do. However, many do not and need to be directed (Iyer, 2009:85). Again, Management by Walking Around is defined as unstructured 
approach to hand-on, direct participation by managers in the work related affairs of their staff in contrast to rigid and distant management (Oliver, 2009:37).

\section{Managerial Skills That Aid Management By Walking Around:- Human Resource Skills:-}

One of the essential ingredients of any successful management is the ability to handle people effectively with believe that employees are the greatest asset. Managing people is said to be the most difficult aspect of organizational life. Machines and other factors of production are worthless unless activated by human resources. Yet humans are always very unstable in character due to social, technological, economical and cultural factors within their environment. Human resource management is the process of acquiring, training, appraising, and compensating employees, and attending to their labor relations, health and safety and fairness concerns. Workers give their best when they know that their interest is well protected. Every individual in the organization has his or her personal objective aside the organization objectives. Both must be recognized in organization for there to be commitment on the part of subordinates. Treating the staff with high sense of respect and dignity motivates workers to put in their best (Dessler, 2005:4).

\section{Competency:-}

This is all about the managers having technical knowledge of their subordinates work. This is the ground upon which they can correct or advice their subordinates on their work. Managers must have knowledge in at least major activities in the organization. It helps managers to direct the subordinates aright. Managers have to acquire all the traditional management skills, marketing, finance, cost accounting, resource allocation, product development etc. Managers have also to master the management arts like writing, speaking, strategy, negotiation, appraisal, ethics, clairvoyance, etc. Besides, managers have to demonstrate qualities of leadership and integrity; and play the role of friends, mentor and coach. Managers use all these knowledge to improve employee and invariably organizational performance (Iyer, 2009:34).

\section{Conceptual Skill:-}

This skill shows the direction an organization is going and how managers intend to reach there. Managers must know where they want organizations to go before they can direct their subordinates. They know the vision and mission of organizations and relate same to their subordinates. As managers they are the chief executive officers who know where they want their organizations to be now and in the future and thereby direct activities of everybody towards achieving them. Managers decide what to be done. They analyze the activities, decisions, and relationships needed. They classify work and divide them into manageable activities and further divide the activities into manageable jobs. They group these units and jobs into departments there after set organization structures. They think through directions that suite organizations, strengthens and circumvent weaknesses (Weihrich, et al, 2010:5).

\section{Communication Skills:-}

Managers have communication skills to send or put their messages across to the subordinates without hindrance. They relate with their staff through communication. Communication is the activity of conveying information through the exchange of ideas, feelings, intentions, attitudes, expectations, perceptions or commands as by speech, non verbal gestures, writings, behaviours and possibly by means of electromagnetic. It is the meaningful exchange of information between two or more people. Communication is also a process by which meaning is assigned and conveyed in an attempt to create shared understanding (Berio, 1960:172, Berko et al, 2010:9). Effective communication occurs when a desired effect is the result of intentional or unintentional information sharing which is interpreted between multiple entities and acted on a desired way. In today's enterprises, information flow faster than ever before. Obtaining information frequently requires getting information from mangers' supervisors and subordinates and also from departments and even from people elsewhere in the organization. In an effective organization communication flows in various directions: downward, upward, and crosswise. Managers who cannot communicate find it difficult to relate with subordinates let alone communicating their vision, mission, goals and objectives of their organizations. Excellent communication skills are at the root of effective management.

\section{Listening Skill:-}

These are skills that encourage managers to give audience to subordinates observation. It is skills that give subordinates impression that they are being recognized or being accorded their due respect. It is by listening to the subordinates that managers are intoned with the developments in their organizations. Managers are expected to hear out their workers before concluding on any matter whatsoever. They must listen to their subordinates even if they 
had the intention of not making use of their suggestions. Listening ability presents managers as being caring and humble. And this attracts respect for them as their workers hold then in high esteem. It also creates good management-subordinates relationship which results in harmonious organizations. Listening skills are all about building trustworthy relationship and also alignment of thoughts, words and actions (Iyer, 2007:90).

\section{Training / Teaching Skills:-}

Management by Walking Around is not limited to observation, inspection or discussing with employees about their work. It also involves seeking ways of improving work of their subordinate where it is discovered that employees are falling short of expectations. Managers have the skill of teaching and also in determining the type of training that is required to improve the performance of employees. Training and teaching are important not only to improve knowledge of already existing methods but also exposing employees to new technologies and procedures. Employees need training and retraining in order to be abreast of new and current technological advancements. No organization can do without training if not they will sooner or later go into obsolesce. Managers have major purpose to provide for the continuation of organizations over time. Training helps to develop employees that will take over from the present managers and this ensures continuation of organizations after their present managers leave (Brown, 1999:29).

\section{Conditions For Successful Management By Walking Around:- Being Aware of Objectives:-}

For management by walking around to be meaningful and profitable to organizations managers must ensure that their activities, corrections, guidelines etc are align with the objectives of their organizations. Again activity that does not agree with the objectives is simply a distraction. And it has to be stopped immediately. Every activity that is worth carrying out in organizations must contribute to the achievement of objectives. In management terms, an objective is an end in view or a goal to be sought. Once the objectives have been set, they become the key criteria against which all managerial and organization activities and decisions are made and evaluated. Objectives seek to impose direction, purpose and meaning to the operations of a firm and to individual or group efforts and are targets which people seek to achieve over a time period (Akpala, 1990:48).

\section{Respect the Unity of Command Principle:-}

In carrying out management by walking around the principle of unity of command must not be violated. Managers must do it with the subordinates immediate supervisors are being sidelined. Employees' supervisors must be present. This is because they are the people that will ensure that errors observed are corrected. They are also the people that will go with the teaching and training of employees. They are also the people that will intimate employees' real intents of management. That management decides to see things for themselves do not mean that they are taking over jobs of supervisors. Not far from it. Management by walking around is only meant to be an interaction or informal visit of managers to intimate employees the direction their organizations are going and how they can be of help.

\section{Do it yourself:-}

Management by walking around is an activity that must be carried out by managers themselves. It cannot be done by proxy. It is meant for the managers to observe things by themselves and form their opinions. The concept calls on managers to get up from behind their desk and move about to see things for themselves. This is done in order to collect first hand information instead of relying solely on information that comes through the ranks which in most cases have been adulterated in favour of the senders. Therefore management by walking around cannot be delegated. Managers do it by themselves. It is one on one interaction between the management and employees. This means given the employee full attention including adopting appropriate body language (Adler, 1997:120).

\section{It is Continuous:-}

Carrying out management by walking around, manager must do it as often as possible. It must be a continuous exercise. This will send the message among all organizational members how serious and committed management are about the programme. It also emphasizes the importance that is attached to it. It is only when management shows this kind of seriousness that employee will take it seriously themselves. Commitment is needed in order to achieve positive results. Management by walking around is unlikely to be effective unless perceived by employees as part of broader genuine belief by management in giving time to listen to, and understand, the feelings and problem of their organizations and employees (News from and Davies, 1993:109). 


\section{Ask Questions:-}

Management by walking around is an activity in which managers seek to find out true situation of things in their organizations. To extract information managers must ask questions. Ask questions where there is the need for clarification for better understanding of the situation prevalent in the organization or on the particular work of a staff. Ask for ideas on ways to improve work being done. Employees may know how best to do their work, but organizational rules or rigid procedures may prevent them from doing so. Questions must be asked in such a way that expresses the desire of managers to elicit solution to a problem. Ask question and do not criticize the work of employees. Questions must be in form of interaction between friends and not in form of master-subordinate relationship. Managers must create conducive atmosphere in organizations such that employees will feel free interacting with managers. Managers need to adopt a positive attitude towards employees and develop spirit of mutual cooperation.

\section{Honesty in Assessment:-}

Honesty leads to trust. Managers not only being honest, they must be seen to be honest by employees so that there will be mutual trust. There is need to be genuine with intention about their organizations and not to use it against any employee. But, it is directed towards a better performance for the benefit of staff and the organization. If managers have such misplaced intentions surely employees being defensive all the time instead of being real and truthful. Managers must be honest to ensure that what they hear from the direction report is actually truth. Honesty creates trust between both parties. Managers as leaders are expected to live above board. Managers must show that they can be trusted and therefore treat employees as partners in progress (Omo-Ikirodah, 1998:256).

\section{Fairness and Justice:-}

Whichever way managers choose to carryout management by walking around it must be extended to everybody whose work is important to the achievement of organizational objectives. Managers must treat employees fairly and according to merit. Ensure justice in treatment. Employees expect certain outcomes in exchanging for certain contributions or inputs. A feeling of inequality creates tension and instigates employees to indulge in certain forms of behavior in order to challenge the perceived inequality. Managers who choose to be selective in their dealings with their employees create disharmony in the organization. A straight and just behavior by managers make employees to trust and believe in their managers (Mullin, 2007:458).

\section{Understand Human Psychology:-}

Managers need to understand main influences on behavior in work organizations and the nature of the peopleorganization relationship. Managers must understand individual differences. People differ both in the thinking and behavior. They do not understand things at the same rate. Again people make mistakes. Managers bear in mind that employees are bound to make mistakes even when they have been instructed on how best to carry out their work. Again it is also important to remember that employees have emotion. And therefore must be handled with utmost respect. Employees experience fears, joy, anger and sadness. They have feelings. Managers always have these in mind and therefore fashion how best to relate with each employee in order to achieve best result. Understanding psychological makeup of employees, make it easier for managers to deal with them and achieve results (Mullins, 2007:25).

\section{Effects Of Management By Walking Around:- \\ Strengthens Relationship:-}

One on one interaction between managers and employees build trust and strengthens relationship. It also creates sense of oneness among organization participants. Given attention to inter-facing with employees with the intention of helping them improve their performance help in boosting managers-employees relationship. This is because they engage in truthful discussion where each expresses his or her observation freely without hindrances. Managers' value people, treat them fairly and with respect. This involves giving employees full attention including adopting appropriate body language. This creates trust. However, this is possible only when employees are sure that management is honest and sincere about the whole exercise. Lack of trust is one of the greatest sources of waste of time and resources (Gralton, 2000:12).

\section{Provides Genuine Information:-}

Organizational performance is dependent on amount of accurate, timely etc of information available to it. Information about employees, equipments and external environment are highly needed for organizations to improve their performance. And since human resources is the most critical factor of organization resources information about 
them is paramount to organization performance. Information, correctly used is power. That is why today managers go to information, rather than information coming to them. With the right information managers can do almost everything (Iyer, 2009:83). Lack of information can be due to failure to get sufficient relevant facts; lack of knowledge or understanding of full requirements; misinterpretation of available information, inaccurate definition of problem or the project itself etc. It exposes problems associated with employee performance and ultimately organization performance. Managers' attention is therefore drawn to problems existing in their organizations.

\section{A Source of Motivation:-}

Management by walking around provides the opportunity for managers and employees to interact one-on-one. Through this managers take particular interest in the work of employees and their personal problems that affect their performance in the organization. Showing concern for both personal and work related problems is a source of motivation to employees. And when employees are motivated their productivity are affected and organizational performance are improved. Attitude of managers increase as well as boost morale of employees. A sincere word of thanks from the right persons at the right time means more to employees. Showing interest in the work of employees creates sense of recognition. Employees are motivated when they know that eyes of managers are reaching where they are. They try to meet the demands of organizations. Human being is the only factor of production that can produce more than their inputs if properly motivated. Managers given' audience to employees is enough to motivate employees. This is because every human being likes to be listened to. And when this is done they tend to be free to discuss any problem most especially the one they encounter in the course of their work (Schneider and Barselix, 2005:167).

\section{It Draws Attention to Organizations Value:-}

Management by walking around always direct and remind employees of organizational values. It makes it easy for managers to redirect employees in area where they are viewing off standards. Every organization has its values, cultures and objectives and every organization activities are directed towards them. Any behavior, activity, operation etc, that does not accord with the values, and objectives of organization is nothing but a distraction. Interaction of managers and employees kind of re-orientate employees on the value of their organizations. Values are actually what differentiates an organization from others and guarantees achievement of objectives and gaining of reputation. It also states what an organization stands for. It is the philosophy of organization. And it is the mind of every manager to always keep employees in line with the values of organizations. This value in most cases develop into cultures of organizations i.e. the way organizations do their things, and the way it relates with other organizations and the general public as a whole. It expresses managers' commitment towards achievement of organizational objectives and also shows or explains how employees' efforts contribute to achievement of organization objectives (Thompson and McHugh, 2002:76).

\section{It Facilitates Achievement of Objectives:}

The whole essence of management by walking around is to improve the performance of organizational members. Put in another way it is meant to improve productivity of employees and invariably organizational performance. As employees increase their productivity organization objectives are therefore easily achieved. All activities in organization are directed towards objectives. Objectives evaluate performance of every organization members. Therefore, an essential task of managers is the formulation, clarification and communication of objectives (Akpala, 1990:48).

\section{Improve Team Performance:-}

Management by walking around actively engages in building team. These managers achieve by creating a good atmosphere. It is therefore their job and responsibility to be cheerful, considerate, polite and helpful. This is because employees are most important resources. It is through and with them that managers achieve organizational objectives. Managers cannot work alone. Without employees managers are nothing, but with them they can achieve objectives. Therefore they must work as a team for the benefit of both and organizations. And the best way to do that is to inspire loyalty and create a team spirit. If managers and employees can work together, chances are that objectives will be achieved thereby creating a team spirit. Organizations grow into some sort of families. Now organizational member need not to love each other, but they have to be a family. And managers have to be head of these families. Managers must live above board in order to be respected, looked up to, trusted and relied upon. For managers to achieve objectives they must build teams that are open and transparent to each other such that managers are ready to fight for their team. By making sure that all the equipment and facilities that employees need for improved performance is needed (Templar, 2005:46). 


\section{It Helps Managers Have Full Grasp of Situation:-}

Management by walking around helps managers have full grasp of what is happening in their organizations. The concept is all about relating with employees to discuss their work and the challenges they face in their work and the organization in general. An open and honest discussion exposes weaknesses of employees and the organizations. This enables managers to have full grasp of situations in their organization. Being in full grasp helps managers to tackle those issues that confront employees and organizations. That means that managers are enabled to be in control of their issues in organization. A knowledgeable manager is a boost to organization performance (Peeling, 2009:139).

\section{Assists Reward of Hard-work and Commitment:-}

It recognizes and rewards hard-work by employees who are putting their best effort toward ensuring organization achieves objectives. Managers Employees are motivated when their efforts and contributions are recognized especially their manager. Management by Working Around offers managers the opportunity of encouraging and praising of employees whose work are outstanding. This propels employees to greater productivity.

\section{Research Methodology:-}

This section gives an introduction to the methodology that was adopted and used in the study. The study is on understanding management by walking around and its effects on organizational performance in the Intafact Beverages Limited, Onitsha, Anambra State of Nigeria. A descriptive survey research design was used in the study. A target of 578 sample population was selected. And the questionnaires returned were 568. The sample distribution cut across all strata of organizational levels - Managers, and subordinates.

\section{Effects Of Management By Walking Around On Organization Performance:-}

The table below shows the effects of management by walking around on organizational performance.

Table 1:-Effects of Management by Walking Around

\begin{tabular}{|l|l|l|}
\hline $\begin{array}{l}\text { Effects of Management by walking } \\
\text { Around }\end{array}$ & Frequency & Percentage (\%) \\
\hline Yes & 455 & $80.1 \%$ \\
\hline No & 113 & $19.9 \%$ \\
\hline Total & 568 & 100 \\
\hline
\end{tabular}

From the table 455 respondents representing $80.1 \%$ agree that management by walking around has effects on organizational performance of Intafact Beverage Limited. While 113 respondents representing $19.9 \%$ maintain that management by walking around has no effect on organizational performance.

Extent Of Effects Of Management By Walking Around On Organizational Performance:-

The figure below shows to what extent management by walking around affects organizational performance.

Extent of effects of Management by walking around

\begin{tabular}{lll} 
High & - & $57 \%$ \\
Very high & - & $24 \%$ \\
Low & - & $13 \%$ \\
Very Low & - & $6 \%$ \\
Total & - & $\mathbf{1 0 0 \%}$ \\
\hline
\end{tabular}

Figure 1:-Extent of Effects of Management by Walking Around on Organization Performance

From the table above $57 \%$ of the respondent state that management by walking around has high effects on organizational performance. $24 \%$ of respondents maintain that management by walking around has very high effects on organizational performance, while $13 \%$ of respondent have different views. They insist that management by walking around has low effects on organizational performance. Again, 6\% of respondents also maintain that the concept has very low effects on organizational performance. 
Statistics:-

\begin{tabular}{|c|c|c|c|c|c|c|c|}
\hline & $\begin{array}{l}\text { Managemen } \\
\text { t by walking } \\
\text { around } \\
\text { strengthens } \\
\text { relationship } \\
\text { of } \\
\text { managemen } \\
\text { t and } \\
\text { subordinates }\end{array}$ & $\begin{array}{c}\text { Managemen } \\
\text { t by } \\
\text { working } \\
\text { around } \\
\text { presents } \\
\text { genuine } \\
\text { information }\end{array}$ & $\begin{array}{c}\text { It is a } \\
\text { source of } \\
\text { motivatio } \\
\mathrm{n} \text { for } \\
\text { those who } \\
\text { are } \\
\text { committe } \\
\mathrm{d} \text { to their } \\
\text { work }\end{array}$ & $\begin{array}{l}\text { It draws } \\
\text { attention to } \\
\text { organization' } \\
\text { s value }\end{array}$ & $\begin{array}{c}\text { Achievemen } \\
\text { t of } \\
\text { objectives is } \\
\text { facilitated } \\
\text { through } \\
\text { management } \\
\text { by working } \\
\text { around }\end{array}$ & $\begin{array}{l}\text { Managemen } \\
\mathrm{t} \text { by walking } \\
\text { around } \\
\text { promotes } \\
\text { team work }\end{array}$ & $\begin{array}{c}\text { It helps } \\
\text { managers } \\
\text { have full } \\
\text { grasp of the } \\
\text { situation in } \\
\text { organizatio } \\
n\end{array}$ \\
\hline $\begin{array}{l}\mathrm{N} \\
\text { Valid }\end{array}$ & 568 & 568 & 568 & 568 & 568 & 558 & 558 \\
\hline Missing & 0 & 0 & 0 & 0 & 0 & 0 & 0 \\
\hline Mean & 1.7394 & 2.1673 & 1.8468 & 1.8116 & 1.5563 & 1.4624 & 1.7993 \\
\hline Median & 2.0000 & 2.0000 & 2.0000 & 2.0000 & 2.0000 & 1.0000 & 2.0000 \\
\hline Mode & 1.00 & 2.00 & 2.00 & 2.00 & 1.00 & 1.00 & 2.00 \\
\hline $\begin{array}{l}\text { Std. } \\
\text { Deviation }\end{array}$ & .92338 & 1.26066 & 1.08027 & .75224 & .77913 & .55035 & .84692 \\
\hline Minimum & 1.00 & 1.00 & 1.00 & 1.00 & 1.00 & 1.00 & 1.00 \\
\hline $\begin{array}{l}\text { Maximu } \\
\mathrm{m}\end{array}$ & 5.00 & 5.00 & 5.00 & 4.00 & 4.00 & 4.00 & 5.00 \\
\hline Sum & 988.00 & 1231.00 & 1049.00 & 1029.00 & 884.00 & 816.00 & 1004.00 \\
\hline
\end{tabular}

Figure 2:-The statistics table shows clearly that management by working around provides bases for evidence based management. It aids the achievement of organization objectives.

\section{Conclusion:-}

1. Communication skill is a means by which managers put their messages across to organization members.

2. Management by walking around always aligns with objectives of organizations.

3. Respect for unity of command principle is necessary for successful management by walking around.

4. Management by walking around cannot be done by proxy.

5. Management by walking around strengthens relationship among organization members.

6. It also provides genuine information to managers.

7. Management by walking around is a source of motivation to employees.

\section{Recommendations:-}

1. Managers should have the technical competence to direct employees rightly.

2. They should have a vision where they intend to take their organization to.

3. Managers should improve on their listening ability in order to elicit genuine response from employees.

4. Management by walking around should be a continuous activity.

5. In carrying out management by walking around managers should be ready to ask questions.

6. Managers should be fair and just to all organizational members.

7. They should be honest in their assessment of employees.

8. Management by walking around should contribute to achievement of objectives. 


\section{References:-}

1. Adler, N. (1997), International Dimensions of Organizational Behaviour, Boston: PWS-Kent

2. Bario, D. (1960), The Process of Communication, Urbana, Illinois, University of Illinois Press

3. Brown, S. (1999), Fatal Errors Managers Make Benin City, Beulahland Publishing Ministry.

4. Dessler, G. (2005), Human Resources Management, London, Pearson Education.

5. Grathon, L. (2000), Living Strategy: Putting People at the Heart of Corporate Purpose, Financial time, Prentice Hall.

6. Imaga, E.U.L. and Ewurum, W.F. (1998), Business Management Topics, Enugu Oktek Publishers.

7. Iyer, S. (2009), Managing for Value, Delhi, New Age Publishers.

8. McCormick, M. (2009), Leadership Elements: A Guide to Building Trust, Google Book Link: Books G -Toc 51

9. Mullins, L. (2007), Management and Organizational Behaviour, Delhi, Pearsons.

10. Newstrom, J. and Davis, K. (1993), Organizational Behaviour: Human Behaviour at Work, New York; McGraw-Hill

11. Oliver, S. (2009), Managing by Walking Around, http://www.futurecent.com//mainbwa/htn,business Dictionary.com

12. Omo-Ikiroda, J. (1998). The A-Z Handbook For Businessman Benin City, Christian Network

13. Peeling, N. (2008), Brilliant Manager, New York, Pearsons.

14. Peter, T. and Waterman, R. (1982), In Search of Excellence, Web Books g-Foc-289.

15. Schneider, S. and Barsonx J. (2003), Managing..........Culture Financial Times Prentice Hall

16. Stone, J. (1978), Management London, Prentice Hall.

17. Templar, R. (2005), Rules of Management, Great Britain, Pearson.

18. Thompson, P and McHugh, D. (2002) Work Organization: A critical Introduction Third Ed. Palgrave. 